\title{
The psychosocial predisposition effects in second language learning: motivational profile in portuguese and catalan samples
}

SANDra Figueiredo and CARLos SILVA

Universidade de Aveiro, Portugal

Received: 19 September 2007 / Accepted: 12 November 2007

ISSN: $1697-7467$

\begin{abstract}
This present study examines the non-linguistic outcomes of second language learners groups and the data for this study were collected from an application of a tests battery - BAMA (motivational, affective and learning aspects assessment), developed in $\mathrm{PhD}$ research context. Were found differences between children and adolescents (305 Portuguese and 279 Catalan immigrant students), regarding motivation and attitudes in the second language learning and psychosocial adaptation contexts, taking into account their nationalities, mother tongues, age and gender. The children and female Catalan present the most favourable means, as predictors in the languages learning, what we can relate to previous research. In other hand, the Portuguese sample presents a distinct other profile, which could be compromising the language learning and psychosocial development. Key-Words: Second Language Acquisition, Cognition, Attitudes, Motivation, Age and Gender.
\end{abstract}

*This PhD research is sponsored by Foundation for Science and Technology (FCT), Portugal, with the grant reference SFRH/BD/24819/2005.

RESUMEN: En la aplicación de la batería- BAMA (que evalúa motivación, factores afectivos y aprendizaje), en el contexto de investigación de doctorado, encontramos diferencias en la motivación y las actitudes hacia el aprendizaje de segundas lenguas y su adaptación psicosocial entre niños y adolescentes, 305 portugueses y 279 estudiantes catalanes de origen inmigrante. Las diferencias observadas están relacionadas con la nacionalidad, la lengua materna, la edad y el género. Los estudiantes más jóvenes y las chicas catalanas obtienen medias más favorables que predicen mejores resultados en el aprendizaje de lenguas, como en otros estudios. Los alumnos portugueses presentan el otro perfil que podría comprometer el aprendizaje de idiomas y el desarrollo psicosocial. Palabras-Clave: Adquisición de segunda lengua, cognición, actitudes, motivación, edad y género.

\section{INTRODUCTION}

Over the last two decades, increasingly more studies have been made on the field of language acquisition, and the various relationships identified in the acquisition process: motivational, affective, cognitive, and biological factors, which directly affect academic success 
and in the development of a balanced mentally healthy person. The science faces the diversity in which our nations find themselves, and tries to explain, through different research avenues, how the language learner develops in his effort to learn and acquire the language as a social global being. The rates and routes of migration have contributed, in addition to the economic and political issue, to the understanding of how the skills and abilities of the subjects and how the psychological restrains can jeopardize these.

In this study, after a short theoretical revision, we will show part of a battery of tests assessing psychological aspects in a specific context of second language (L2) learning, as well as some inferences resulting from applying these tests to a total sample of 584 students (first phase in Barcelona and the second in Portugal) with migratory experience and with an age range of 7 to 21 years old. The data collected and discussed will concern perception differences between child and adolescent, and also between genders, regarding various dimensions of motivation, the attitude and the differences of declared anxiety of the subject in the context of second language learning both inside and outside the classroom. Our object is to show how two distinct samples (Catalan and Portuguese) show different profiles on the level of these psychological factors especially in respect to age.

\section{Cognitive and pSychological accounts of Second-language ACQUISITION: LANGUAGE LEARNER'S PROFILE}

The research has essentially two different fields in the second language acquisition area: the cognition and the psychological dimensions. In each of them we find theoretical and empirical basis that determine boundaries between the perspectives that must be related. In this PhD project we developed two instruments to apply in the same nuclear sample. These instruments regard the psychological and the cognitive aspects to attend a holistic assessment in the second language context. In one hand, the aim is to assess the phonological awareness and general cognitive abilities of younger and older learners. In other hand, we look for the differences between children and adolescents in the motivation, anxiety and learning styles, in the second language learning/acquisition context. In fact the cognitive and maturational constraints, for some authors, are the factors most implied in the explanation of the differences between the language learners, because those factors are based on the biological facts,

(...) behavioural developments that have sudden onsets and offsets (the critical period timing), result in all-or-nothing events, depend on instinct, are unlearned and irreversible, and for which environmental influences such as motivation do not play any role (Hyltenstam \& Abrahamsson, 2005: 556).

Nevertheless, other authors consider the affective filtering factor as the main one,

(...) social factors conspire to ease the effort for young children by providing a nurturing environment, simplified input, educational opportunities, cooperative peers, and other supporting aspects of a social context that facilitate the acquisition of any language (Hyltenstam, Abrahamsson, 2005: 570). 
The subject with migratory experience is affected on various personal levels (Lier, 2004; Lantolf, 2000) related with the languages learning (the five selves). The communication competence is directly related to self-esteem and self confidence and motivation of the learner and as a social being. These dimensions develop at different time rates, when the learner is in a different context. This cause a confrontation on a ecological and interpersonal level (Lier 2004: 118) and it is the self termed conceptual that is most affected in the context of L2 learning, since this implies expectations, investment, motivation, notion of power control and self discursive (Lier 2004: 118). We have here what Lier calls «theory of me», where identity, roles, beliefs of the me are found (Clyne, n.d.). This generates an attitude and position that influences the perception of competence and the perception of the other. The attitudes, in preference to the motives, have a greater influence in the L2 learning process and a 4/5-yearold child already shows an attitude and decision that leads towards a target. The literacy skills acquisition is determined by the psychosocial predisposition of the individual. According to authors such as Snow (1998) the children with migratory experience presents higher risk of failure in their literacy skills than the other individuals. Various studies, done in the same scientific field, come to assert the fact that personality (extrovert/introvert), motivation (not only of integrative but also instrumental), socio-cultural attitude (assimilation/generalization, influence of family background) and cognition (strategies and learning styles) are the selfanalysis driving the languages learner. According to McLaughlin (1985) this is more evident especially as the subject gets older. It is interesting to see how Gillette concludes in his studies that the strategies of the learner of a second language (L2) are mere symptoms of certain predispositions - motivational, personal, socio-cultural and cognitive - which have to be learnt quickly (the strategies) to get success in the linguistic and social tasks. Gardner (2003) did a meta-analysis in order to research the relationship between the five variables of the socio educational model (Gardner, 2005): integration, attitudes towards the learning situation, motivation, integrative orientation, and instrumental orientation. According to the contributions of other studies in the second language learning area and the related psychological factors, the results prove that the correlations between the academic success (in language learning) and motivation show such a significant congruence not found in the same relationship between the success in learning and other variables. On the other hand, authors such as Rod (1989) believe that a study based in the analysis of the intervenient factors in the second language learning, requires looking at learning process and the learner as a whole. Dörney (2003) understands the manipulated human action in simultaneous, physical and psychological contexts, determining and affecting cognition, behaviour and success. The child learns the language by feeling and linguistic sense, but inevitably the meta-language of the child is violated by the imposition of rules without the exercise of reflection. Each student has a ISL (individual system of language) and a ILF (individual linguistic factor - different code levels, at the time of communication). Both languages (if this is the case) do not enter in vacuum, but into the student, through his process of filtering where the individual characteristics of the subject act - «in discenti» (Cazacu, 1979). It is not enough to learn to read, write, speak and listen; there is also the acquisition of behavioural patterns different from those which we are used to (Sanz, 2005).

Regarding the issue of motivation, we find, in an intrinsic manner, the attitude and the motive, but attitude is something more constant: «not liable to much change» (Baker, 1997: 60 ), whereas the motive is something more immediate, reactive to a stimulus. According to 
the framework of Gardner $(1972 ; 1985 ; 2005)$, motive and attitudes are on the same level: learning the language is the combination of the learning effort and the positive attitudes towards the language being learnt. The lower the motivation, the more negatives these attitudes are, the greater the anxiety, in a compromising sense in the course of learning and of the psychosocial construction. In the relationship between learning, personal development and motivation and anxiety we find the affective filter hypothesis of Krashen (1989) applied to the specific issue of L2 learning. Adolescence emerges as critical period in the process of Second Language acquisition, not only at the level of maturation (neurocognitive), but also by the existence of affective filters that compromise input data to be processed (Figueiredo \& Silva, 2006). The more the personality is consolidated, the more difficult it is to learn a new linguistic code. Filtering begins the process of «monitorization» (Krashen, 1989) which occurs when conscience (not the awareness sense) dominates the learning process and the affective maturation, which is still being developed in the child. As a matter of fact the issue of competence and performance in the L2 could be explained by the articulation of cognitive, social and psychological factors, which could be exercising a greater influence and be more explanatory than the biological influence, in the experience of learning related with the age factor (Moyer, 2004). Besides the cognitive differences between the age groups, explained by neurobiology and neuropsychology perspectives (Lenneberg, 1967; Gullberg \& Indefrey, 2006, Patkowsky, 1999; Pallier, 2002; Nagai, 1997; Levy, 2007; Bialystok, 1999; Doughty, 2005; Johnson 1991), regarding the emotional plan, it is much more unusual for an adult to engage in the second language learning than for a younger individual (Clyne n.d.). There is a biological clock for the cognitive aspect but also for the emotional which becomes much more active from adolescence on, and therefore, can compromise the latency supporting learning (in the sense of acquisition and not learning, Krashen, 1989). This «latency» is natural of childhood - incidental learning (acquisition as the natural way of learning, without instruction). Identity, learning and migratory experience are related, as «...second language learning in all of its aspects requires the individual, take on a new identity, to a certain extent» (Guiora, 1972: 145).

The cognitive changes are more visible in the context of the Second than in the First Language, given that the "automaticity» level drastically diminishes in an adult, compared to a child. Processing rhythm, working memory, declarative memory, and attention are skills involved in different stages of L2 acquisition that, with the age advancing and language use, are changed and decline. Regarding procedural memory, it declines with age, which is evident in the difficulty that the adults reveal in grammar learning. According to Krashen (1989), from five years old onwards language learning becomes a more rigid process, therefore entering in the formal domain, once the sensitive period has finished. This does not mean that the adult learner will not be able to learn the grammar of a foreign or second language. However the adult will not make it in acquisition circumstances, but in the intentional and explicit learning way. At the semantic level, however, there is not a sensitive period for its acquisition; it is a process that can be developed in any age (Neville \& Bavelier, 1998; Stowe \& Sabourin, 2005; Gullberg \& Indefrey, 2006). The assumption that children are more proficient than older people in learning situations is related to the effect of the critical periods ('readiness') for specific acquisitions and skills training that occur in certain human developmental stages. The concepts mentioned up to here (learning, acquisition, intentional/incidental and explicit learning, automaticity) are related with the notion of critical period, established by Lenneberg 
(1967). In the context of language acquisition, it would be more correct to talk about a «sensitive period» or plasticity period, not a «susceptibility period», and we must consider the biological perspective that justifies the sensitivity of the organism to several functions (Bialystok \& Miller, 1999: 128). There are skills that can only be developed during the proper time, and are related to the plastic potential given by the specific neuronal circuits involved in developing such capacities. The notion of sensitive period is not applied only to the second language acquisition, given that the process of first language acquisition so has a plasticity period, being that the environmental experience intervenes predominantly in the process and in its success.

The Age factor, and also nationality and gender, are influencing the differences in the cognitive and affective aspects, both necessary to the well achievement. The classical emotional latency of the youngest learners could provide a language acquisition and incidental learning without blockages, at least, avoiding some of them which interfere mainly in the second language learning. In other way, the older ones could have a better performance because have acquired already the abstract skill to the cognitive processing and also to the social conceptualization.

\section{Method}

\subsection{Participants}

The Tests Battery was applied to two different groups of participants: Catalans and Portuguese students with migratory experience. In the study done in Spain (Barcelona), there were 279 students, 128 children (9-12) and 151 adolescents (13-17) from several schools. 99 students were from European countries, 47 from America, 47 were born in Asian countries and 8 from Africa.

In the case of the Portuguese sample, there were 305 individuals, 126 children (7-12 years old) and 178 (13-21 years old) adolescents, from several schools of Aveiro, Portugal. 146 were from European countries, 95 were born in America, 9 were from Asia and 51 from Africa.

\subsection{Materials}

A self-assessment instrument was developed for this study, assessing Motivational, Affective and Learning Aspects (BAMA), composed the sub-scales "Proficiency", "Motivation and Attitudes", "Learning Styles", "Anxiety", "Stress" and "Depression". The scale contains 23 items, which the individuals answer choosing one of 7 intervals on a dimension that varies between two opposing poles. The "Motivation and Attitudes" sub-scale is an adaptation from the MINI-AMTB of Masgoret, Gardner \& Bernaus (2001) whose translation into Portuguese was done independent translators (the translation had two confirmation phases), one by the researcher and the other by one of the authors of the test, in order to meet the theoretical and conceptual requirements. In the Catalan study the sub-scale "Motivation and attitudes" this scale with 12 items showed a good internal consistency with alpha cronbach $=.717$. The items show correlations with the final score of between .267 and .664. In the factorial analysis, with 
rotation varimax for values equal or superior to 1,3 factors were found: "Motivation and attitude towards the Language" (items 1, 2, 3, 4, 7, 9, 11 and 12), "Anxiety" (items 8 and 10) and "Learning situation and Teacher" (items 5 and 6). The alpha would increase if factor "Anxiety" (items) are deleted. However, we did not delete them, because this increase would be minimal and because this is an important factor for this research. The higher the totals of the factors, the more favourable will be the motivation and attitude towards Language, the greater the anxiety and the more favourable will be the attitude towards L2 (second language) learning and the teacher. The sub-scale "Motivation and attitudes" (in the case of the Portuguese study) contains 10 items and shows good internal consistency with alpha cronbach=.73. Items show correlations with a total value between .357 and .788 , positive and very significant $(\mathrm{p}<.001)$. In the factorial analysis, with rotation varimax, we found 3 factors: "Motivation in Second Language learning» (items 1, 4, 5, 9 and 10), "Attitudes towards the teacher, class and community" (2, 6 and 8) «Interest in Foreign Languages and Instrumental Orientation» (items 3 and 7). The alpha increased significantly with the elimination of two items that had been added to the scale: "attitudes towards own nationality" and "attitudes towards the teaching of MT (mother tongue in school), will not be considered. We found that this factorial analysis differs from the one observed in the same scale, in the Catalan version, applied to immigrant students in Barcelona, in the first phase of the study. In that phase three were completed, however the items were distributed in a different way, since only factor 1 of both studies were similar, which already shows differences between the two samples. The bigger the values of the totals of the factors, the more favourable will be "Motivation in PL2 learning", the bigger the "Attitudes towards the teacher, class and community" and the more positive will be the factor "Interest in Foreign Languages and Instrumental Orientation".

Besides this scale we used a set of items, to record personal data (gender, present school, nationality of the participant, age, year of schooling, birth place, date of birth, date of arrival in Catalonia, nationalities of parents, and home languages).

\subsection{Procedures}

The tests were presented in a questionnaire format, to the 584 participants in their schools, between October 2006 and February 2007. Each individual application took 30 minutes.

\subsection{Data analysis}

We achieve the Average, Standard Deviation, Frequencies, Percentages, Pearson Correlations, Independent Samples T Tests, Factorial Analysis with Rotation Method (Varimax with Kaiser normalization), as well as Multifactorial Multivariate Analysis of variance (multiway ANOVA). To achieve this we used the programme SPSS 14.0 and 15.0.

\section{RESUlts}

Regarding the differences in Motivation and attitude towards the language, (in the Catalan study), between the categories «Nationality», «Home languages» we did not find any statistically 
significant differences between the respective categories. In the categories of different «Age groups», group I (children- 9-12 years old) leads with 49,2 followed by group II (adolescents and adults-13-21 years old) with 42,8 . The correlation is significant at the $\mathrm{p}<.000$ level, between the two categories. Look at the table n. ${ }^{\circ} 1$.

Table n.1. Age and «Motivation and Attitude» scales (Factor 1) in the Catalan study.

\begin{tabular}{|c|c|c|c|c|c|}
\hline Dependent Variable & (l) Age & (J) Age & $\begin{array}{l}\text { Mean } \\
\text { Difference } \\
(I-J)\end{array}$ & Std. Error & Sig.(a) \\
\hline & & & $\begin{array}{l}\text { Lower } \\
\text { Bound }\end{array}$ & Upper Bound & Lower Bound \\
\hline \multirow{2}{*}{$\begin{array}{l}\text { AMTB } \\
\text { Factor } 1\end{array}$} & $9-12$ & 13-17 & $6,406\left(^{*}\right)$ & 1,282 &, 000 \\
\hline & $13-17$ & $9-12$ & $-6,406\left(^{*}\right)$ & 1,282 &, 000 \\
\hline \multirow[t]{2}{*}{$\begin{array}{l}\text { Anxiety } \\
\text { Factor } 2\end{array}$} & $9-12$ & 13-17 & $-1,867\left(^{*}\right)$ & ,571 & ,001 \\
\hline & $13-17$ & $9-12$ & $1,867\left(^{*}\right)$ & ,571 & ,001 \\
\hline \multirow[t]{2}{*}{$\begin{array}{l}\text { Learning Situation } \\
\text { Factor } 3\end{array}$} & $9-12$ & 13-17 & 1,128 & ,853 & ,187 \\
\hline & 13-17 & $9-12$ & $-1,128$ & ,853 & ,187 \\
\hline
\end{tabular}

Based on estimated marginal means

* The mean difference is significant at the, 05 level.

a Adjustment for multiple comparisons: Least Significant Difference (equivalent to no adjustments).

The results achieved in the relation between the "Age Group", and «Motivation and Attitudes towards L2 Learning» (Factor I in the Portuguese version, similar to Factor I of the Catalan version "Motivation and Attitude towards Language") is different for the Portuguese immigrants. The children show a better average $(30,4)$ as opposed to the group of adolescents $(29,3)$ but without statistical significance. In the specific context of the Portuguese immigrant students, "Attitudes towards the Teacher, Class and Community" (Factor II), only the category "Languages Spoken at Home" appears as a factor influencing the results. The Romance Languages Speakers and the Portuguese Language Speakers are the groups with better results $(19,9)$ in this variable factor, followed by the other groups: Speakers of Slavic Languages (19,5), Speakers of Arabic/Chinese Languages (19,3), Multilingual (18,01) and Creoles Languages Speakers $(14,1)$. Look at the table n. ${ }^{\circ}$. 
Table n.2. Age and "Motivation and Attitude scales» (3 factors) in the Portuguese Study.

\begin{tabular}{|l|l|l|l|l|l|}
\hline $\begin{array}{l}\text { Dependent } \\
\text { Variable }\end{array}$ & (I) Age & (J) Age & Mean Difference (I-J) & Std. Error & Sig.(a) \\
\hline & & & Lower Bound & Upper Bound & $\begin{array}{l}\text { Lower } \\
\text { Bound }\end{array}$ \\
\hline $\begin{array}{l}\text { AMTB } \\
\text { Factor 1 }\end{array}$ & $7-12$ & $13-21$ & 1,099 & 1,029 &, 288 \\
$\begin{array}{l}\text { AMTB } \\
\text { Factor 2 }\end{array}$ & $7-12$ & $13-21$ &, 288 & 1,029 &, 288 \\
& $13-21$ & $7-12$ &,- 288 &, 556 &, 605 \\
$\begin{array}{l}\text { AMTB } \\
\text { Factor 3 }\end{array}$ & $7-12$ & $13-21$ &, 081 &, 556 &, 605 \\
& $13-21$ & $7-12$ &,- 081 &, 461 &, 861 \\
\hline
\end{tabular}

Based on estimated marginal means

* The mean difference is significant at the, 05 level.

a Adjustment for multiple comparisons: Least Significant Difference (equivalent to no adjustments).

In the comparative analysis between genders regarding "Motivation and attitude towards Language" (Factor I Catalan version), the female part shows a better average $(49,2)$ while the males show $(45,5)$. The difference is very significant $(p<.002)$ between the categories "gender". The variable age varies in the inversion reason in a very significant manner with the following variables dependent on "Motivation and attitude towards the language" $(\mathrm{r}=-0,383 ; \mathrm{p}<.01)$ and the learning situation and the teacher (Factor II $\mathrm{r}=-0,170 ; \mathrm{p}<.05)$. The variable depending on motivation and attitudes show a positive correlation and very significant with Anxiety $(\mathrm{r}=-0,320 ; \mathrm{p}<.01)$, Factor III of the sub-scale. Regarding «Motivation», in the case of Factor I of the Portuguese version, the female sector that has the higher average $(31,1 \%)$ and with a significant difference between the two genders $(\mathrm{p}<.011)$. For factor II and III, the female sector also shows more favourable averages (Factor II: 18,9; Factor III: 12,0), but without significant differences. The variable age varies in the inversion reason and in a significant manner with AMTB $1(-.137, \mathrm{p}<.05)$. Maintains the inversion reason but without significant relation with AMTB2 (-.095). The Proficiency shows a positive correlation and very significant with AMTB1 $(\mathrm{p}<.01, .240)$, with AMTB2 $(\mathrm{p}<.01, .340)$ and with AMTB3 $(\mathrm{p}<.01, .251)$. Regarding variables AMTB1, 2 and 3 , there is a very positive relationship 
$(\mathrm{p}<.01)$ between AMTB1 and AMTB2 (.340) and between AMTB1 and AMTB3 (.251); between AMTB2 and AMTB3 the relationship is positive and significant $(p<.05, .171)$. Look at the table n.2.

\section{Discussion}

In the study on immigrant Catalan students, with respect to Motivation and attitudes and more specifically «Motivation and attitudes towards language» (Factor I), we found that the nationality of the subject and the languages he speaks do not influence significantly their motivation and attitudes. On the other hand age is a dominant factor with group I ( $<12$ years) with the highest average followed by group II ( $>12$ years), with a very significant difference between the two groups. We reached the conclusion that the older the children get, they show lower indices of motivation and positive attitudes. Therefore it is the children that show higher motivation and more positive attitudes in the various situations related with the learning of the dominant language. With these empirical data is suggested that is expected more optimism from younger individuals ( $<12$ years), which could be related with not being aware of the negativity of the social situation and learning. In the case of older subjects, that becomes more peculiar and will interfere in the academic success. The child always shows a higher score in respect of «Integration guidance». Attitudes towards the native speakers of Catalan (as a group) and the "interest in foreign languages", which agrees with a study by Lambert e Klineberg (1967), where it was proved that age is a differentiating factor. It is in Childhood that we find a greater receptivity and positive approach to the introduction of cultural differences. Children accept differences with greater ease and are never uninterested. In a study (Almeida, 1996) regarding style of field (in)dependence as seen in children and adolescents, we found that children are more field dependant because they are more aware of the social environment and more dependent on the action of the teacher (more social orientation), thus also more confident in external references. We can also conclude, from the first sample (Catalan students) that, as the subjects get older, even just one year, there is a significant difference on decreasing of positive attitudes and motivation toward the dominant group, the Catalans.

We also found that the most integrating guidance (Noels, 2003) of the child promotes the aptitude for language acquisition, and therefore it is generally understood that in that group there are higher levels of proficiency. The flexibility of the child is still cognitive and social (Gardner \& Lambert, 1972). However, according to Faerch and Kasper (1987), the second language learners (adults) are favoured by «Instrumental Guidance» because the social intention is predominant as also the motive for learning and perfecting the L2. We can, taking this conclusion into account, understand that age is the biggest factor in respect of evolution and guidance in the integration content of the instrument, as there are other priorities, and it is the social ones that dominate. Thus «Instruments Orientation» is not less positive as suggested by Gardner \& Lambert (1972), they are mere reasons that act more a less positively in the phases of development of the human being. The social orientation referred earlier (Almeida, 1991), identified in the children is not involved in the instrumental profile but with the dependence that the child shows and needs in relationship to his environment as "primary social learner" becoming as he gets older "activator of social values". 
In the comparison between variables we saw that the bigger the proficiency, the more favourable are the motivation and attitudes. This justifies the fact that the children show positive indices of motivation and attitude, as it is also the group of the younger ones that have the greatest proficiency. In the study with the sample of the Portuguese immigrants, the profile is distinct, especially in respect of age. The nationality and the mother tongue of the subjects are influencing factors, not the age factor, as found in the study of the Catalan sample. Regarding the motivation for learning a second language (Factor I of the scale of Motivation and Attitudes), it is the group of individuals born in the Asian continent that show the best motivation indices. The reason could be the great difference between the mother tongue they speak and the difficulty of integration could motivate the sense of learning that they believe is essential to achieve it. Although the differences are significant, in the Catalan study, we found that, the opposite occurs in the case of Asian nationality (and African) who show set types of orientation. However their motivational components are the lowest, compared to the Europeans and the Americans (Latin). The American group shows a very low motivation for learning of L2, which contrasts with the results achieved in proficiency. We could now suggest that the individuals, who felt that they have already achieved proficiency, do not show motivation in that learning because it is already completed. Therefore the profile explained here is the following: the Americans (especially those from Latin America) show high levels of proficiency, and low levels of motivation in the learning of a second language, and the Asians, show a lower level of proficiency, but a higher level motivation.

On the other hand, the speakers of Indo-European romance languages show a greater motivation, which is not the case with the study made in Barcelona, considering that these would be better adapted and the motivation here would not be so essential to learning. These students were also European (nationality), in the study with the Catalan immigrant students, and revealed the higher levels of proficiency. This proves that the low level of proficiency is also correlated with high motivation, propelled by the need to learn. The personal dimension (Lier, 2004) is affected more when the subject is in a new language context, where attitudes are developed, which will serve as motivational conductor to reach success in competencies and performance. We are here speaking of a sequence necessary to learning: expectation, motivation, research, power, control and discourse. If one of these aspects fail, then the sequence will not be met. However this does not mean that success will not be achieved, because it may not be the personal objective of the individual. In this way, those who feel they have achieved competency, do not generate expectations, neither motivation, therefore do not invest in the same way that would be supposed if the motivational component was there. The Asians are in phase of need which prompting this, in other words, is resumed to a cycle of needs, in pyramid structure. On the other hand, the plurilingual individuals may not understand the learning the language in the same moulds of necessity as the other individuals. Therefore there is not the same investment, they have kind of a "proper ability" and it does not require the start of a new activity, is learnt task.

The most curious aspect, in the Portuguese sample, is there being no significant differences registered between children and adolescents, that is, the age here does not influence the motivation, being more common to find a greater motivation in the younger ones (Lambert \& Klineberg, 1967, Gardner \& Lambert 1972, Masgoret et al. 1985, Gardner 2000, Gardner, 2005). In fact, in this sample, this does not happen which is related to a different psychological predisposition of the child, or probably that must be viewed as the one most affected by the 
social and cultural constraints (Krashen, 1989). Various authors concluded, from empirical data, that it is expected that children are more optimistic and tolerant, regarding cultural differences and new language, due to their mastery of learning. This is favoured in the specific context of languages, by the neurobiological predisposition of the child (critical period hypothesis). The favourable indices of motivation would be naturally associated with an equally more positive proficiency. Here, in the Portuguese group, the children show more proficiency, but are not very distant from the adolescents in respect of motivational profiles (low).

On the level of gender, both in the study with students from Catalonia and from Portugal (immigrants), the feminine gender scores better in this scale. As for the male gender, it correlates with the best perception of proficiency (assessed on scale of self-evaluation) that the same gender reveals and proves in various bilingual competencies (Gardner \& Lambert, 1972). The female gender is more "available" for bicultural adaptation and acceptance. (Baker, 2003). This situation occurs when they are users of more than one language and become able to use both with the same proficiency (study in Louisiana, Gardner \& Lambert, 1972). In a more specific analysis, it was found that the female gender shows higher and more significant values, when compared with the male gender, in respect of item "Integration organisation", meeting the requirements of the general studies (Duquette \& Laurier, 2000). This proves that the female shows more affectionate and socially dependent in the learning of another language. We found that, especially with the Catalan sample, with a younger and preferably female audience, the socio-educational model of Gardner (2005) shows good results. As the author believes, that model works when there is positive correlation with favourable indices in «Integrative Orientation», «Motivation» and «attitude», minimizing the intervention considered less encouraging, although the other two constructs that integrate the model: «Instrumental Orientation» and «Anxiety» are part of the model. In fact, the female students have great motivation, positive attitudes and are driven by integrativeness.

\section{Conclusion}

In a general conclusion, regarding the previous data, we can confirm the basic research hypothesis of this present study - other variables than age are related in the psychosocial predisposition to the languages acquisition; distinct profiles in the samples observed due to affective and motivational factors - and, particularly, we can find a stronger relation between the lower aptitude towards the L2 acquisition and learning and the less social predisposition that individuals reveal themselves. Therefore various studies have found that in the case of children a greater sociability is associated also with their ability. Ausubel, contrary to other authors such as Gardner (1972, 2005), Bishop (2001), Baker (1997), Krashen (1989), Lantolf (2000), McLaughlin (1985), Duquette and Laurier (2000), Snow (1998), Centeno (2005), considers motivation unnecessary, because cognition is the first need manifested by the human being and this leads to the other. It is this author that discusses the issue of the adolescents being more satellizer, because they are more de-motivated and "oppressed" by the affective component which is not manifested in children (non satellizer) in the same way. The fact of there being more linearity, from a general point of view, in the positive average that children obtained through various scales, is justified by the fact that the children are in development 
phase. This stage the child is acquiring, in parallel, linguistic and social knowledge (Bishop, 2000) and there is no overlapping. However immigrant Portuguese children do not fit this profile, but are closer to the psychosocial structure of the adolescent. There are attitudes, motivation, affective states, that the migrant child shows differently and his development is much faster (than the monolingual) which could hinder or promote their linguistic learning. The acquisition of languages, not in learning sense, is more positive for the child than for the adolescent or the adult. If an early learner of languages shows certain cognitive capacities (Gullberg \& Indefrey, 2006) before a monolingual child would, than the psychological development is part of this process and is also particular.

\section{REFERENCES}

Almeida, Leandro S. (1991) Cognição e aprendizagem escolar (Cognition and scholar learning). Porto: Associação de Psicólogos Portugueses.

Ausubel, Paul D. (1968). Educational Psychology. New York: Holt, Rinehart and Winston.

Baker, Colin. (1997). Foundations of bilingual education and bilingualism. Clevedon: Multilingual Matters Ltd.

Baker, S. \& MacIntyre, P. (2003). The role of gender and immersion in communication and second language orientations. Language Learning, 53: 65-96.

Bernaus, M., Masgoret, A.-M., Gardner, R.C., \& Reyes, E. (2004). Motivation and Attitudes toward Learning Languages in Multicultural Classrooms. International Journal of Multilingualism, 1(2): 75-89.

Bialystok, E. \& Miller, B. (1999). The problem of age in second-language acquisition: influences from language, structure, and task. In Bilingualism: Language and Cognition, 2 (2): $127-$ 145.

Centeno, J. G. (2005). Bilingual Speech-Language Pathology Consultants in Culturally Diverse Schools: Considerations on theoretically-based consultee engagement. Journal of Educational and Psychological consultation, 16(4): 333-347.

Clyne, S. (n.d). Psychological Factors in Second Language Acquisition: why your international students are sudando la gota gorda (sweating buckets). Retrieved May 7, 2006, from http://www.bhcc.mass.edu/PDFs/TFOT PsychFactors2ndLang.pdf.

Dörnyei, Z. (2003). Introduction. Language Learning, 53: 1-2. Blackwell Publishing.

Doughty, C. \& Long, M. H. (2005). The handbook of second language acquisition. Malden: Blackwell Publishing.

Duquette, L., \& Laurier, M. (eds.) (2000). Apprendre une langue dans un environment multimedia (Learn a language in a multimedia environment). Outremont: Editions Logiques.

Faerch, C. \& Kasper, G. (1987). Introspection in Second Language Research. Clevedon: Multilingual Matters.

Figueiredo, S. \& Silva, C. (2006). "A activação do desenvolvimento psicológico em alunos imigrantes" (Psychological development activation in immigrant students). In Tavares, J. et al. (eds.). Activação do Desenvolvimento Psicológico: Actas do Simpósio Internacional, 279-285. Aveiro: Universidade de Aveiro.

Gardner R.C. \& Lambert W.E. (1972). Attitudes and motivation in second-language learning. Rowley: Newbury House.

Gardner R.C. (1985). The Attitude Motivation Test Battery Manual. Canadá: University of Western Ontario. 
Gardner, R.C. (2005). The Socio-educational Model of Second-Language Acquisition: A research paradigm. Eurosla Yearbook, 6: 237-260.

Guiora, A. (1972). Construct Validity and Transpositional Research: Toward an Empirical Study of Psychoanalytic Concepts. Comprehensive Psychiatry 13, 139-150.

Gullberg M. \& Indefrey, P. (2006). The cognitive Neuroscience of Second Language Acquisition. John Schumann (ed.). Oxford: Blackwell Publishing, Ltd.

Hyltenstam, K. \& Abrahamsson, N. (2005). Maturational Constraints in SLA. In Doughty, C. Long, M. H. (eds.). The handbook of second language acquisition, 539-589. Malden: Blackwell Publishing.

Krashen, S. D. (1989). Language acquisition and language education. New York: Prentice Hall. Johnson J. S. \& Newport E. L. (1991). Critical periods effects on universal properties of language: the status of subjacency in the acquisition of a second language. Cognition, 39, 215-58.

Lantolf, J. (2000). Sociocultural theory and second language learning. Oxford: University Press.

Lenneberg, E. H. (1967) Biological Foundations of language. New York: John Wiley.

Levy, J. B. et alii. (2007). Inhibiting your native language: the role of retrieval-induced forgetting during second-language acquisition. Psychological Science, 18(1), 29.

Lier, L.(2004). The Ecology and Semiotics of Language Learning: a sociocultural perspective. Boston: Kluwer Academic Publishers.

Lovibond, P.F. \& Lovibond, S.H. (1995). The Depression Anxiety Stress Scales (DASS). Retrieved in April 5, 2006, from http://www2.psy.unsw.edu.au/groups/dass.

Lovibond \& Lovibond (1995). Depression Anxiety Stress Scale 42 (DASS 42) Retrieved in April 5, 2006, from http://www.swin.edu.au/victims/resources/assessment/affect/dass42.html

MacIntyre, P., Baker, S., Clément, R. \& Donovan, L. (2003). Sex and Age Effects on willingness to communicate, anxiety, perceived competence, and L2 motivation among junior high school French immersion students. Language Learning, 53: 137-166.

Masgoret, A. M., Garner, R. C. \& Bernaus, M. (2001). Examining the role of attitudes and motivation outside of he formal classroom: A test of he mini-AMTB for children. In Q.Dornyei, Z. \& Schmidt, R. (eds.). Motivation and Second Language Acquisition. Honolulu: University of Hawai'i Press.

McLaughlin, B. (1985). Second-Language acquisition in childhood, 2. School-age children, second edition. London: Lawrence Erlbaum Associates

Moyer, A. (2004). Age, Accent and Experience in Second Language Acquisition. An Integrated Approach to Critical Period Inquiry. Clevedon: Multilingual Matters (Second Language Acquisition).

Nagai, K. (1997). A concept of critical period for language acquisition. Its implication for adult language learning. Bulletin of the Society for the Study of English Education, 32: 39-56.

Noels, K., Pelletier, L. Clément, R. \& Vallerand, R. (2003). Why are you learning a second language? Motivational orientations and self-determination theory. Language Learning, 53: 33-64.

Noels, K. (2003). Learning Spanish as a second language: learner's orientations and perceptions of their teacher's communication style. Language Learning, 53: 33-64.

Pallier (2002). Brain imaging of language plasticity in adopted adults: can a second language replace the first? Cerebral Cortex, in press.

Patkowsky, M. (1990). Age and Accent in a Second Language: a reply to James Emil Flege. Applied Linguistics, 11(1): 73-89.

Rod, E. (1989). Second Language Learning and Second Language Learners: Growth and Diversity. TESL Canada Journal, 7(1): 74-94. 
Sanz, C. (ed.) (2005). Mind and context in adult second language acquisition: Methods, Theory and Practice. Washington, DC: Georgetown University Press.

Slama-Cazacu, T. (1979). Psicolinguística aplicada ao ensino das línguas (Psycholinguistics applied to the languages teaching). São Paulo: Livraria Pioneira.

Snow, C. E. (ed.) (1998). Preventing reading difficulties in young children. Washington: National Academy Press. 